\title{
THE GEOGRAPHICAL REACH OF INTERNATIONAL HUMANITARIAN LAW IN TRANSNATIONAL ARMED CONFLICT
}

\author{
Elliot Winter*
}

\section{Keywords}

International humanitarian law; law of armed conflict; transnational armed conflict; terrorism; geographical reach; jurisdictional ambit; control; military presence

\begin{abstract}
Non-international armed conflicts between States and organised armed groups are a reality of warfare. Since the emergence of the 1949 Geneva Conventions, these conflicts have been regulated by international humanitarian law. However, a subset of this category known as transnational armed conflict has seen aggressive proliferation over recent decades as groups such as ISIS have taken advantage of the internet and other technologies to expand their reach beyond national frontiers and strike States around the world. This phenomenon has left the geographical extent of international humanitarian law - which has historically relied on State boundaries to determine its ambit-unclear. This article examines the main options for delimiting the geographical reach of the regime in transnational armed conflicts. It considers approaches based on international boundaries; 'hot battlefields'; global application and territorial control before ultimately concluding that a method based on 'military presence' would be the most suitable standard.
\end{abstract}

\section{Introduction}

On 29 November 2019, the London Bridge attack saw two people killed and three more wounded by Usman Khan. The Islamic State of Iraq and Syria (ISIS) ${ }^{1}$ claimed responsibility for Khan's actions shortly thereafter. ${ }^{2}$ What happened on London Bridge is just a recent example in a long line of terrorist strikes launched by radical Islamic groups against Western targets since the millennium. Other notable examples include the Paris attacks of 2015 whereby a series of terrorist strikes shocked the city and left hundreds dead and wounded; ' $7 / 7$ ' in London and, of course, '9/11' in New York. ${ }^{3}$ Despite the diminution in power of ISIS as a political and military entity - encapsulated by its routing from its 'capital' Raqqa in 2017 - the group still has a significant following and even today retains control of pockets of territory in the Middle East and Africa. The capacity of ISIS, and groups like it, to mount strikes against what they consider to be enemy States anywhere in the world means that the matter of how to address transnational terrorism has retained a prominent position in the security agenda of many governments. For example, the United Kingdom (UK) renewed its decision to 'prioritise the fight against terrorism' as part of its latest review of the National Security Strategy. ${ }^{4}$

In order to address this threat, the argument of some Western powers has been that terrorist attacks launched by organised armed groups provide a legal basis for military action in self-defence under the law on the use of force ${ }^{5}$ and that, under international humanitarian law (IHL) - which governs the

\footnotetext{
* Elliot Winter, Lecturer, Newcastle University Law School. Email elliot.winter@newcastle.ac.uk.

${ }^{1}$ I Black, 'The Islamic State: Is it Isis, Isil - or Possibly Daesh?' The Guardian (London, 21 September 2014)

$<$ https://bit.ly/32GcOlH $>$.

${ }^{2}$ C Giordano, 'London Bridge Attack: ISIS Claims Responsibility' Independent (London, 01 December 2019)

$<$ https://bit.ly/2ENkh9Y>.

${ }^{3}$ The Wall Street Journal, 'Timeline of Terror Attacks in Past 20 Years', The Wall Street Journal (New York, 07 January

2015) <https://on.wsj.com/3hTqyQt $>$.

${ }^{4}$ HM Government, National Security Strategy and Strategic Defence and Security Review 2015: A Secure and

Prosperous United Kingdom (HMSO 2015) $11<$ https://bit.ly/3hFKplL>.

${ }^{5}$ C Tams, 'The Use of Force Against Terrorists' (2009) 20(2) European Journal of International Law 359, 373.
} 
conduct of hostilities - strikes can legitimately be directed at such groups whatever their location. In the United States (US), the early approach of the Bush Administration was to proclaim the existence of a 'war on terrorism' 6 and, in 2012, Barack Obama referred to the 'global war on terrorism' in the course of authorising further Congressional funding intended to combat it. ${ }^{7}$ In a 2015 statement concerning ISIS, President Obama said:

I have made it clear that we will hunt down terrorists who threaten our country, wherever they are. That means I will not hesitate to take action against [ISIS] in Syria, as well as Iraq. This is a core principle of my presidency: If you threaten America, you will find no safe haven [emphasis added]. ${ }^{8}$

This was not empty rhetoric. For a number of years thereafter, Western States mounted strikes against various terrorist groups in the Middle East with, for example, the UK's House of Commons voting to extend strikes against ISIS in Iraq to Syria in the wake of the Obama administration's statement. ${ }^{9}$ More recently, despite enormous policy differences with Obama in other areas, the Trump administration had generally held this 'no safe haven' stance and actively targeted ISIS in other countries. Perhaps most notably, the US targeted the then leader of ISIS, Abu Bakr al-Baghdadi, who died during a 2019 raid. In the 2020 Republican National Convention, President Trump celebrated this as one of his key successes in office, proclaiming 'we've defeated the ISIS caliphate and killed al Baghdadi'. ${ }^{10}$ With political upsides such as this, it seems assured that taking an expansive approach to tackling terrorist groups will remain a feature of Western policy for years to come; even under the new, and likely less hawkish, Biden administration.

The assumption, or perhaps desire, of States in this context is that IHL applies as the lex specialis, thereby displacing or modifying domestic law or international human rights law, ${ }^{11}$ with the effect that their conduct is permitted. After all, as the International Committee of the Red Cross (ICRC) has observed, 'IHL rules governing the use of force and detention for security reasons are less restrictive than the rules applicable outside of armed conflicts governed by other bodies of law'. ${ }^{12}$ However, there is much uncertainty as to the precise geographical reach of IHL in this context owing in part to the fact that Geneva Conventions $\mathrm{I}^{13}, \mathrm{II}^{14}, \mathrm{III}^{15}$ and $\mathrm{IV}^{16}$ (and their Additional Protocols $\mathrm{I}^{17}$ and $\mathrm{II}^{18}$ ) have no explicit territorial ambit. This was highlighted by the International Criminal Tribunal for the

\footnotetext{
${ }^{6} \mathrm{CNN}$, 'Transcript of President Bush's Address to a Joint Session of Congress' (CNN, 20 September 2011)

$<$ https://cnn.it/34NrZfy>.

${ }^{7}$ B Obama, 'Letter to John Boehner' (Office of the White House, 28 September 2012).

${ }^{8}$ B Obama, 'Statement by the President on ISIL' (The White House, 10 September 2014) < https://bit.ly/31v7oSY>.

${ }^{9}$ E Piper and K MacLellan, 'Parliament Votes to Bomb Islamic State in Syria' (Reuters, 03 December 2015)

$<$ https://reut.rs/34LgZiB $>$.

${ }^{10}$ C-SPAN, 'President Trump Speaks at 2020 Republican National Convention Vote' (C-SPAN, 24 August 2020)

$<$ https://cs.pn/2EEzv1t $>$.

${ }^{11}$ M Milanovic, 'A Norm Conflict Perspective on the Relationship between International Humanitarian Law and Human Rights Law' (2012) 14(3) Journal of Conflict and Security Law 459.

12 ICRC, 'International Humanitarian Law and the Challenges of Contemporary Armed Conflicts' (ICRC, 01 December 2011) <https://bit.ly/32D50AZ>.

${ }^{13}$ Convention (I) for the Amelioration of the Condition of the Wounded and Sick in Armed Forces in the Field (adopted 12 August 1949, entered into force 21 October 1950) 75 UNTS 31.

${ }^{14}$ Convention (II) for the Amelioration of the Condition of Wounded, Sick and Shipwrecked Members of Armed Forces at Sea (adopted 12 August 1949, entered into force 21 October 1950) 75 UNTS 85.

${ }^{15}$ Convention (III) Relative to the Treatment of Prisoners of War (adopted 12 August 1949, entered into force 21 October 1950) 75 UNTS 135.

${ }^{16}$ Convention (IV) Relative to the Protection of Civilian Persons in Time of War (adopted 12 August 1949, entered into force 21 October 1950) 78 UNTS 287.

${ }^{17}$ Protocol Additional to the Geneva Conventions of 12 August 1949, and relating to the Protection of Victims of International Armed Conflicts (adopted 08 June 1977, entered into force 07 December 1978) 1125 UNTS 3.

${ }^{18}$ Protocol Additional to the Geneva Conventions of 12 August 1949, and Relating to the Protection of Victims of NonInternational Armed Conflicts (adopted 08 June 1977, entered into force 07 December 1978) 1125 UNTS 609.
} 
Former Yugoslavia (ICTY) in Tadic in which the Tribunal noted that 'the Geneva Conventions are silent as to the geographical scope of international "armed conflicts". ${ }^{19}$ The result of this ambiguity is that States run the risk of applying the wrong set of rules in the context of counter-terrorism operations. This would distort the ambit of IHL and could lead simultaneously to violations of international law on one hand and unduly restrained use of military force on the other.

This article seeks to bring greater clarity to the matter of the 'legal geography of war' 20 and the proper reach of IHL in situations where States are engaged in what have loosely been called 'transnational armed conflicts ${ }^{21}$ with terrorist groups. It will consider the principal alternatives in this field: international boundary based application; 'hot battlefield' based application; 'global application' and territorial control based application of IHL. However, these will ultimately be dismissed in favour of a topical application of the regime based on the mechanism of 'military presence'. It should be noted that this article will not consider issues such as the qualification of groups such as ISIS and Al Qaeda as 'organised armed groups' or the legal criteria for the establishment of 'non-international armed conflicts' (NIACs) between such groups and States like the US and UK. For an exposition of these points, one may consult the work of Mack and Reeves who establish that, for example, ISIS is an organised armed group and that a NIAC exists between that group and the US. ${ }^{22}$ Here, those preliminary considerations are presumed to have been satisfied so that focus may remain squarely on the reach of IHL. One preliminary matter that we must still consider, however, is how the actions of individuals are to be attributed to these organised armed groups (and thus the broader non-State actors of which they form part). In other words, how can we attribute the actions of an individual, such as Khan, to a wider group such as ISIS? Certainly, it takes more than the individual's assertion that they carried out the attack on the group's behalf. There are two principal answers to this point: 'membership' and 'adoption of responsibility'.

Regarding 'membership' of an organised armed group, the ICRC's interpretive guidance on direct participation in hostilities (DPH Guidance) is instructive. ${ }^{23}$ The DPH Guidance notes that membership in these groups has no basis in domestic law and is rarely formalised with written contracts, uniforms and so on. ${ }^{24}$ Instead, 'the decisive criterion for individual membership in an organized armed group is whether a person assumes a continuous function for the group involving his or her direct participation in hostilities (hereafter: "continuous combat function")'. ${ }^{25}$ The DPH Guidance goes on to give suggestions of what particular activities would qualify under this heading and lists examples including 'the preparation, execution, or command of acts or operations' ${ }^{26}$ The approach taken in the DPH Guidance is not without its criticisms. For example, for Akande, it creates a lack of equality between the State and non-State forces because 'any member of the armed forces of a State ... is a legitimate target at all times, including the cook, the cleaner, the lawyer and others without a combat function' whereas in organised armed groups 'individuals who do not have a continuous combat function will be civilians ... immune from direct attack' ${ }^{27}$ Notwithstanding such

\footnotetext{
${ }^{19}$ Prosecutor v Dusko Tadic (Decision on the Defence Motion for Interlocutory Appeal on Jurisdiction) ICTY-94-1-A (02 October 1995) para 68.

${ }^{20} \mathrm{~K}$ Anderson, 'Targeted Killing and Drone Warfare: How We Came to Debate Whether There is a "Legal Geography of War"” (2011) 16 American University Washington College of Law 3.

${ }^{21}$ M Sassoli, 'Transnational Armed Groups and International Humanitarian Law' (2006) Harvard University Program on Humanitarian Policy and Conflict Research (Occasional Paper Series) <https://bit.ly/31 IanzD>.

${ }^{22}$ EC Westbrook Mack and SR Reeves, 'Tethering the Law of Armed Conflict to Operational Practice: Organized Armed Group Membership in the Age of ISIS' (2018) 36 Berkeley Journal of International Law 334, 345.

${ }^{23}$ Nils Melzer, Interpretive Guidance on the Notion of Direct Participation in Hostilities under International Humanitarian Law (ICRC 2009).

24 ibid 32-33.

25 ibid 33.

26 ibid 34.

${ }^{27}$ D Akande, 'Clearing the Fog of War - The ICRC's Interpretive Guidance on Direct Participation in Hostilities' (2010)

59 International and Comparative Law Quarterly 180, 186.
} 
criticisms, the position is considered to be generally satisfactory and certainly adequate for present purposes.

Regarding 'adoption of responsibility' by an organised armed group, the actions of any individual can be 'claimed' after the fact. The starting point here is outlined it the International Law Commission's Articles on Responsibility of States which provide that 'conduct which is not attributable to a State ... shall nevertheless be considered an act of that State under international law if and to the extent that the State acknowledges and adopts the conduct in question as its own'. ${ }^{28}$ By definition, the Articles were intended to apply only to States and not to organised armed groups belonging to non-State actors such as ISIS or Al Qaeda. Nonetheless, the same logic applies and these groups should also be able to 'adopt' the conduct of individuals or cells who purport to have operated on their behalf. Indeed, in practice, this is what happened in the example given above, with ISIS adopting responsibility for Khan's attacks on London Bridge. ${ }^{29}$ If terrorist groups wish to reap the propagandistic gains of associating themselves with such actions then they must equally be prepared to assume the consequences. The stage having been set, we can now proceed to consider the various options available for measuring the legal geography of war.

\section{International Boundary Based Application of IHL}

Perhaps the simplest starting point for a discussion of the ambit of IHL is the traditional model. In its default state, IHL is assumed to follow international boundaries with the result that it generally applies to the '(i) land areas; (ii) internal waters; (iii) archipelagic waters; (iv) territorial sea; (v) subsoil and submarine areas underneath these expanses of land and water, as well as the continental shelf; and (vi) the superjacent airspace' of the States concerned. ${ }^{30}$ This approach is unsurprising given that the law was designed primarily with international armed conflicts (IACs) between States in mind. In that context, it makes eminent sense.

This 'international boundary' approach was then carried over to NIACs between States and organised armed groups. For example, according to the commentary to Additional Protocol II (which concerns the protection of civilians in NIACs), "persons affected by the conflict within the meaning of this paragraph are covered by the Protocol wherever they are in the territory of the State engaged in conflict' [emphasis added]. ${ }^{31}$ One can also construe Tadic as supporting this view as the Tribunal held that IHL must be applied 'in the whole territory under the control of a party'. ${ }^{32}$ Given that one of the parties to a NIAC is likely to be a State with 'control' of its whole territory, this boundarybased model has been taken to involve the extension of IHL throughout the affected State. More explicitly, the ICTY noted that 'the provisions suggest that at least some of the provisions of the Conventions apply to the entire territory of the Parties to the conflict'.${ }^{33}$ Here, the ICTY had in mind those provisions which concern the protection of civilians - particularly common Article 3 to the Geneva Conventions and those safeguards found in Additional Protocol II. ${ }^{34}$ This view was reaffirmed in the later decision of the Tribunal in Blaskic. ${ }^{35}$

Valid though it may be, it must be emphasised that this boundary based approach was conceived and

\footnotetext{
${ }^{28}$ International Law Commission, 'Draft Articles on Responsibility of States for Internationally Wrongful Acts' Supplement No. 10 (A/56/10) Chapter IV.E.1, art 11.

${ }^{29}$ Giordano (n 2).

${ }^{30}$ Y Dinstein, War, Aggression and Self-Defense ( $3^{\text {rd }}$ ed, CUP 2001) 19.

${ }^{31} \mathrm{~J}$ Pictet et al, Commentary on the Additional Protocols of 08 June 1977 to the Geneva Conventions of 12 August 1949 (Martinus Nijhoff 1987) para 4490.

${ }^{32}$ Tadic (n 19) para 70.

33 ibid para 68.

34 ibid para 69.

${ }^{35}$ Prosecutor v Tihomir Blaskic (Trial Judgment) ICTY-95-14-T (03 March 2000) para 64.
} 
applied in the context of an internal NIACs (i.e. a conflict between a State and a rebel group within its borders). In such cases, it was simply reasoned that extending the reach of IHL outwards from the fighting right up to the international boundaries of the affected State would be useful by preventing the emergence of gaps in coverage (which might appear if 'hot battlefields' or one of the other options discussed below was used to determine the ambit of IHL). The proponents of the boundary approach presumed that NIACs would only ever concern one State (leaving aside the issue of spill-over conflicts ${ }^{36}$ ). In short, "the only "geography question" that required clarification was to ascertain the reach of the law within the State [emphasis added]'. ${ }^{37}$

Unfortunately, the 'geography question' raised by transnational NIACs (i.e. conflicts between States and organised armed groups that cross State boundaries) had not been reckoned on yet. However, this is precisely the question that groups such as ISIS pose as their activities are not necessarily limited to the confines of one State, or even to a small group of neighbouring states. Admittedly, much of that group's fighting occurred along a corridor of land straddling the frontier between Iraq and Syria with the effect that both States, under the international boundary approach, fell under the ambit of IHL. However, many of the group's adherents also conducted, and continue to conduct, attacks much further afield in Western cities. The scale of the attacks grew to a point where some governments feared that ISIS might launch large scale chemical or biological attacks. ${ }^{38}$ Thus, when confronting terrorist groups now or in the future, it might be attractive for Western States to argue that the whole territory of any countries in which terrorists are found is subject to IHL. After all, the regime permits fighters belonging to organised armed groups to be targeted and killed. ${ }^{39}$ As Kress suggests - with much concern about overreach - IHL might be applied throughout a State in which "there is some "emanation" of the non-State party, for example in the form of the presence of a member of its armed forces'. ${ }^{40}$

This blanket approach cannot be an acceptable solution. IHL, despite all its safeguards, can legitimise the destruction of persons and property which would normally be prohibited in peacetime. As such, its application must be limited to the maximum extent possible while still allowing room for military necessity. ${ }^{41}$ To bring the entire territories of Iraq, Syria, France, the US and the UK (among others) under the auspices of the laws of war would be neither proportionate nor in step with the object and purpose of the law whereby military necessity must be balanced with the requirement to limit human suffering. ${ }^{42}$ Indeed, it is hard to imagine a country which would not have at least one ISIS adherent located within its territory. Therefore, taken to its natural conclusion, the vast majority of the land surface of the globe would find itself under the harsh gaze of IHL. In short, in the context of contemporary scenarios, an international boundary-based approach is not appropriate.

\section{'Hot Battlefield' Based Application of IHL}

With the traditional model discounted, it becomes necessary to consider alternatives. One option is that the application of IHL should be limited to areas which are in the grip of a sufficient level of

\footnotetext{
${ }^{36}$ R Geiss, 'Armed Violence in Fragile States: Low-intensity Conflicts, Spillover Conflicts, and Sporadic Law Enforcement Operations by Third Parties' (2009) 91(873) International Review of the Red Cross 127.

${ }^{37}$ L Arimatsu, 'Territory, Boundaries and the Law of Armed Conflict' (2009) 12 Yearbook of International Humanitarian Law 157, 187.

${ }^{38}$ A Sims, 'Isis “Aggressively Pursuing Development of Chemical Weapons" Say Iraqi and US Officials', The Independent (London, 20 November 2015) <https://bit.ly/34Q5MgW>.

${ }^{39}$ Additional Protocol II (n 18) art 13(2).

${ }^{40}$ C Kress, 'Some Reflections on the International Legal Framework Governing Transnational Armed Conflicts' (2010)

15(2) Journal of Conflict and Security Law 245, 266.

${ }^{41} \mathrm{R}$ Kolb, Advanced Introduction to International Humanitarian Law (Edward Elgar 2014) 77.

${ }^{42}$ E Winter, 'Pillars not Principles: The Status of Humanity and Military Necessity in the Law of Armed Conflict' (2020) 25 Journal of Conflict and Security Law 1.
} 
fighting: known for the sake of convenience as the 'hot battlefield'. According to this approach, IHL only applies where fighting is actually taking place. For example, as O’Connell put it:

That the United States is engaged in armed conflict against al Qaeda in Afghanistan does not mean that the United States can rely on the law of armed conflict to engage suspected associates of al Qaeda in other countries. The application of the law of armed conflict depends on the existence of an armed conflict. Armed conflict exists in the territorially limited zone of intense armed fighting by organized armed groups [emphasis added]. ${ }^{43}$

It is submitted that this approach is flawed. Firstly, the language seems to be inspired by Tadic but, while the decision required 'protracted armed violence between governmental authorities and organized armed groups', ${ }^{44}$ the test was only intended to be used to determine whether or not a noninternational armed conflict exists and not to ascertain the territorial extent of that conflict. Indeed, it was held that 'the temporal and geographical scope of both internal and international armed conflicts extends beyond the exact time and place of hostilities'. ${ }^{45}$ The basis for this reasoning was that any other interpretation would create absurdities whereby IHL could be easily circumvented in the situations where it was most needed. The Tribunal considered the position in IACs and found that:

With respect to prisoners of war, [protection] applies to combatants in the power of the enemy; it makes no difference whether they are kept in the vicinity of hostilities ... [T] he very nature of the [Geneva] Conventions ... dictates their application throughout the territories of the parties to the conflict; any other construction would substantially defeat their purpose [emphasis added]. ${ }^{46}$

While the boundary based approach should be dismissed for the reasons above, the ICTY must surely have been correct that the 'hot-battlefield' approach is also inadequate. For example, to continue with the example of prisoners of war, it is inconceivable that they might lose their protected status if the party into whose hands they have fallen decides to relocate them away from the fighting. Indeed, this would be nonsensical as such prisoners must be moved away from the battlefield under Geneva Convention $\mathrm{III}^{47}$ which provides that 'no prisoner of war may at any time be sent to, or detained in areas where he may be exposed to the fire of the combat zone'. ${ }^{48}$ Of course, prisoner of war status is a special category of protection that only exists in IACs, not NIACs. Still, individuals who are captured in NIACs benefit from some basic protections under Common Article 3 of the Geneva Conventions ${ }^{49}$ and the same logic applies. In other words, it would be absurd to argue that Common Article 3 protection could be circumvented simply by moving a captured person away from the battlefield. If that were the case, those protections would be worthless.

Importantly, the ICTY took the view that the 'hot battlefield' approach would be equally inappropriate for NIACs and that the 'geographical and temporal frame of reference for internal armed conflicts is similarly broad'. ${ }^{50}$ The reasoning behind this was that in such conflicts:

[the] beneficiaries of common Article 3 of the Geneva Conventions are those taking no active part ... in the hostilities. This indicates that the rules ... apply outside the

\footnotetext{
${ }^{43}$ Nasser al Aulaqi v Barack Obama (Declaration of ME O'Connell) United States District Court for the District of Columbia No. 10-CV-01469 (30 August 2010) < https://bit.ly/3jrUtiQ>.

${ }^{44}$ Tadic (n19) para 70.

45 ibid para 67.

46 ibid.

${ }^{47}$ Geneva Convention III (n 15).

48 ibid art 23.

49 ibid art 3(1).

${ }^{50}$ Tadic (n 19) para 69.
} 
narrow geographical context of the actual theatre of combat operations. ${ }^{51}$

As one might expect, humanitarian groups are generally critical of the 'hot battlefield' approach owing to the lacunae in protection its adoption would create. Perhaps ironically, the approach is also becoming unattractive from the point of view of States such as the US which view IHL as an increasingly permissive regime and which would prefer to extend its application much further. For example, according to John Brennan (former director of the Central Intelligence Agency) 'the United States does not view our authority to use military force against al-Qa'ida as being restricted solely to "hot" battlefields".52

In short then, the 'hot battlefield' model is not convincing. It has little legal basis and advocates from both the humanitarian and military ends of the spectrum disapprove of the zones of operation it would create for IHL.

\section{Global Application of IHL}

Thus far, the 'international boundary' and 'hot battlefield' based geographical models for the application of IHL have been rejected. If this is correct, it still leaves open the ambit of the regime in conflicts between States and transnational armed groups. In fact, the lack of a resolution in this area has persisted in discourse on this topic for some time to the extent that it has enabled the emergence of the controversial concept of a 'global battlefield'. ${ }^{53}$ This doctrine essentially argues that the application of IHL cannot realistically be limited to any particular area whatsoever.

For States, the obvious advantage of taking this broadest possible view IHL's scope is that it allows terrorists to be routed wherever they are found. Any other approach based on a more restrictive geographical limitation will inevitably leave certain areas, and hence certain terrorists, beyond the reach of IHL. A narrower ambit might not necessarily be a problem where the States or territories in question are governed by allies of the target State and possess robust criminal law enforcement apparatuses. In such circumstances, terrorists could simply be dealt with by the police or security services. Indeed, we saw the Belgian police offer this sort of assistance to the French authorities in the aftermath of the 2015 Paris attacks when it emerged that Salah Abdeslam was hiding out in Brussels. A warrant was issued by the Belgians and he was eventually apprehended there in 2016 (after an exchange of gunfire) and, in 2018, sentenced to 20 years imprisonment. ${ }^{54}$ However, $^{2}$ individuals such as Abdeslam, and organised armed groups more generally, do not always select places such as Brussels to be their base of operations and instead often opt for areas where they know the local authorities are unable to challenge them or, indeed, where those authorities are unwilling to challenge them because they support such endeavours. Osama bin Laden's hideout in Abbottabad was possibly an example of the latter. According to Lewis, "nations such as Yemen, Somalia, Sudan, and the FATA-area of Pakistan, in which law enforcement actions against organizations like al-Qaeda are either ineffective or intentionally not pursued, would become safe havens if IHL were not applied there'. ${ }^{5}$ He went on to note that 'IHL should not be read to privilege such a group that it actively disfavors in so many other ways'. ${ }^{56}$

\footnotetext{
51 ibid.

52 J Brennan, 'Strengthening Our Security by Adhering to Our Values and Laws' (Speech at the Harvard Program on Law and Security, 16 September 2011) <https://bit.ly/3lzZBU0>.

${ }^{53}$ N Lubell and N Derejko, 'A Global Battlefield: Drones and the Geographical Scope of Armed Conflict' (2013) 11(1) Journal of International Criminal Justice 65.

${ }^{54}$ RK Cragin, 'The November 2015 Paris Attacks: The Impact of Foreign Fighter Returnees' (2017) 61(2) Orbis 212, 224.

${ }^{55}$ M Lewis, 'Drones and the Boundaries of the Battlefield' (2012) 47 Texas International Law Journal 293, $312-313$.

56 ibid 313.
} 
Perhaps the strongest argument in favour of such wide-ranging application of IHL can be found not in the assertion that its ambit is global per se, but in the view that geography is simply irrelevant. According to Lubell:

The applicability of the ius in bello does not depend on the number of miles between the individual and the fighters they are commanding and directing, nor does it stand or fall on whether the individual is sitting on one side of a border or another. The tests are the standard and long-recognized requirements for determining who or what is a legitimate target under IHL. ${ }^{57}$

There is some international practice supporting the view that the reach of IHL should not be overly concerned with territorial boundaries. The United Nations Security Council (UNSC) resolution that acts as the founding document of the International Criminal Tribunal for Rwanda (ICTR) provides that the Tribunal may 'prosecute persons responsible for serious violations of international humanitarian law committed in the territory of Rwanda and Rwandan citizens responsible for such violations committed in the territory of neighbouring States [emphasis added]' ${ }^{58}$ Similarly, the Resolution provides that the Tribunal's jurisdiction extends not only to Rwanda but to 'the territory of neighbouring States in respect of serious violations of international humanitarian law committed by Rwandan citizens [emphasis added]' ${ }^{59}$ In this sense, the thirteen States on the UNSC at the time which voted for the establishment of the ICTR with this (albeit limited) extra-territorial mandate could be said to favour a geographically relaxed approach to the ambit of IHL. The States which voted for the resolution were France, Russia, the UK, the US, Argentina, Brazil, the Czech Republic, Djibouti, Spain, Nigeria, New Zealand, Oman and Pakistan - China abstained and, perhaps unsurprisingly, Rwanda itself voted against the resolution. While the ICTR's founding resolution is technically a matter of the international criminal law jurisdiction of a specific court rather than the remit of IHL - and while it is calls for nothing remotely as broad as global application of the regime - it remains instructive.

Of course, there is concern that this attitude might result in the unbridled application of IHL simply because an extra-territorial armed group has a presence there. Human Rights Watch has been particularly vocal in its opposition to such a broad application of IHL, arguing that 'the notion that the entire world is automatically by extension a battleground in which the laws of war are applicable is contrary to international law' ${ }^{60}$ Similarly, Geiss notes that 'a sweeping and global application of IHL without any territorial confines whatsoever is not maintainable owing to the unjustifiable worldwide derogations from human rights law this would bring about'. ${ }^{61}$ In essence, the concern is that IHL would displace human right law in almost all situations and that this would be overreach because the comparatively low standard of protection of IHL should only operate where it is simply not feasible for other, more generous, regimes (such as human rights) to function. Of course, on the other hand, States need to be able to effectively grapple with deeply sensitive national security issues such as terrorism. Thus, it seems that a middle road is needed: one which is neither so narrow or blinkered by a preoccupation with national boundaries or where fighting is occurring at any given moment; nor so expansive as to be 'global' and overreaching. The question is how to carve out a suitable compromise.

\section{Territorial Control Based Application of IHL}

\footnotetext{
${ }^{57}$ Lubell and Derejko (n 54) 82.

${ }^{58}$ UNSC Res 955 (08 November 1994) UN Doc S/RES/955 art 1.

59 ibid art 7.

${ }^{60}$ Human Rights Watch, 'Letter to President Barack Obama Re: Targeted Killings and Unmanned Combat Aircraft Systems' (Human Rights Watch, 07 December 2010) < https://bit.ly/3lysnV4>.

${ }^{61}$ Geiss (n 37) 138.
} 
Perhaps the best starting point for a nuanced approach to the ambit of IHL that results in sufficiently well-defined application is Tadic. In Tadic, the judgment makes a clear distinction between Geneva rules (governing the protection of civilians etc.) and Hague rules (governing the conduct of hostilities). As far as the Hague rules are concerned, at one point in the judgment the Tribunal favoured an approach based on control stating that, until a peaceful settlement is achieved, 'international humanitarian law continues to apply ... in the case of [NIACs] to the whole territory under the control of a party, whether or not actual combat takes place there [emphasis added]'. ${ }^{62}$ For example, in a transnational armed conflict between a State such as the UK and a group such as ISIS occurring in Syria, IHL would apply to those areas of that Syria controlled by ISIS.

Of course, the meaning of 'control' is open-textured. We could, for example, borrow a threshold test used for assessing whether a NIAC exists under Additional Protocol II to also determine whether there is sufficient control. One of the criteria of a NIAC for the purposes of that instrument is that the members of the organised armed group can 'exercise such control over a part of its territory as to enable them to carry out sustained and concerted military operations and to implement this Protocol [emphasis added]'. ${ }^{63}$ It might be assumed that there is no particular reason to depart from this test in the present context. In other words, one might argue that, if control is one of the tests used for determining the existence of a NIAC, it could also be used to determine the extent of that NIAC. This would mean, for example, that areas used by ISIS as springboards for routine and orchestrated attacks would fall under the ambit of IHL. At first blush, this is a workable position. However, on closer analysis is quickly, disintegrates. The main problem with a 'control' based approach to the ambit of IHL is that control over territory is often precisely what the opposing sides in a conflict are trying to achieve and the areas over which they clash are thus not within the control of either party. Indeed, historically, the acquisition of territory has been the instigating factor behind conflicts.

The issue of whether ongoing violence precludes control over territory was considered in Al-Skeini. ${ }^{64}$ In that case, the UK House of Lords (UKHL) (predecessor to the UK Supreme Court) held that the degree of resistance in areas of Iraq after the 2003 invasion meant that the UK was not in control of those areas notwithstanding the fact that it was formally an occupier. As Lord Carswell summarised, 'it would ... require a high degree of control by the agents of the state of an area in another state before it could be said that that area was within the jurisdiction of the former. The test for establishing that is and should be stringent, and in my judgment the British presence in Iraq falls well short of that degree of control'. ${ }^{65}$ The issue was considered more recently in Georgia v Russia, a case before the European Court of Human Rights (ECtHR) concerning the 2008 conflict which saw Russian troops and Russian-backed separatists move into South Ossetia and Abkhazia. ${ }^{66}$ There, the Grand Chamber placed great weight on the distinction between the five-day period of what it termed 'active hostilities' and the later period of occupation which came after a ceasefire was agreed. For present purposes, it is the 'active hostilities' period that is relevant and, in that regard, the Court refused to consider the alleged violations of international law during that period as it found that Russian jurisdiction was not established through control over territory. The Court held that:

[I]n the event of military operations ... including, for example, armed attacks, bombing or shelling ... one cannot generally speak of 'effective control' over an area. The very reality of armed confrontation and fighting between enemy military forces seeking to establish control over an area in a context of chaos means that there is no control over an area. This is

\footnotetext{
${ }^{62}$ Tadic (n 19) para 70.

${ }^{63}$ Additional Protocol II (n 18) art 1(1).

${ }^{64}$ Al-Skeini and others $v$ Secretary of State for Defence [2007] UKHL 26.

65 ibid para 97.

${ }^{66}$ Georgia v Russia (No. 2) (Merits Judgment) Application Number 38263/08 (European Court of Human Rights, 21 January 2021).
} 
also true in the present case, given that the majority of the fighting took place in areas which were previously under Georgian control. ${ }^{67}$

The UKHL and ECtHR positions occupy different points on the same spectrum. Both courts took the view that conflict over an area of territory mitigates the likelihood that any party to a conflict has control over that territory. There is a nuance between the two positions, but it is only a matter of degree. The ECtHR is more definitive that violence will preclude 'control' in all but fringe cases, while the UKHL takes the view that violence may preclude control, but it is much more open to examining the circumstances and assessing just how much violence is happening on the ground. One may take a view on which stance is preferable but, for present purposes, it is submitted that both judgments create a fundamental problem by linking the ambit of international law to 'control'. The ECtHR approach - and the suggestion that even minor violence might be enough to displace control - is untenable because it sets the threshold for control much too high. Indeed, it is hard to imagine a conflict where almost every single pocket of resistance could be stamped out for the purposes of meeting the ECtHR's test. Equally, the UKHL position fails to account for the fact that its nuanced approach to control leaves too much ambiguity. War is an inherently dynamic and messy affair and control over an amorphous and ill-defined area may shift unpredictably from one hour to the next such that trying to define which party held control of a given area at a given time seems futile. These difficulties would no doubt be exacerbated by the fact that control is a politically and militarily loaded concept. Each side is likely, from a propaganda perspective, to be eager to claim it has 'control' over a contested area to bolster its position at home and abroad. The consequence of all this is that it would be very difficult to determine with any degree of reliability what areas were under whose control and when - especially when this exercise is performed in a courtroom years after the fact.

To overcome these problems, Kress has suggested that control should be assessed with reference to a lower threshold of where the armed group has a '(quasi-)military presence which enables it to carry out sufficiently intensive armed violence'. ${ }^{68}$ There is some potential in this line of reasoning: the reference to military presence is helpful but the reference to the ability to dispense violence is not. Inevitably there will be locations in which non-State groups such as ISIS are present, in which they field members and from which they carry out various functions but from which they do not, or cannot, launch violent attacks. In such areas, the control-based approach as modified by Kress would still be unsatisfactory as it would lead to gaps in the coverage of IHL. Any naturally occurring gaps might then be exacerbated by deliberately contrived gaps whereby organised armed groups deliberately seek to diffuse their operations across a number of sites so that none of them, taken in isolation, fall within the ambit of IHL but which, taken cumulatively, do afford the ability to carry out intensive violence.

Another difficulty with the position advocated by Kress is that it is not clear why control within an area is to be assessed with reference to the ability to mount intense strikes beyond it. For example, if we accept that the US is involved in a transnational conflict with ISIS, it would be reasonable for the US to wish to target an ISIS outpost in, say, Mali (setting aside jus ad bellum issues). If the outpost constitutes a significant enough military presence, the fact that it cannot, or does not, use that area to directly launch attacks against the US is surely irrelevant. This point is likely to be of great practical significance as many 'terrorist' facilities do not directly contribute to the fighting in the sense of launching strikes but, nevertheless, serve critical ancillary roles as training bases, communications centres, propaganda distributors and so on. Furthermore, where the terrorist group qualifies as a party to a NIAC, such targets would still be legitimate for the purposes of the principle of distinction. ${ }^{69}$

In short, hinging the application of IHL on the control of territory by organised armed groups - even where control is assessed with reference to the ability to project violence - is unworkable. Depending

\footnotetext{
${ }^{67}$ ibid para 126.

${ }^{68}$ Kress (n 41) 266.

${ }^{69}$ Additional Protocol II (n 18) art 13(2).
} 
on the approach taken, it would lead to lead to entire battlespaces falling beyond the ambit of IHL, to intolerable uncertainty in the ambit of IHL or, at best, patchy coverage with large (possibly contrived) gaps.

\section{Military Presence Based Application of IHL}

So where does the rejection of control as the delineating mechanism of IHL in transnational armed conflict leave us? Winding back a little, we can return to Kress' reference to 'military presence'. ${ }^{70}$ While it was a mistake to link military presence to the ability to directly dispense violence, with some adjustment that test could indeed provide a workable solution to the present problem. However, rather than as a sub-test of control, military presence would act as the principal test for triggering IHL. This test could then have its own dedicated sub-tests. Factors which might be used to assess whether or not a cell of a non-State armed group acting extra-territorially exhibits a 'military presence' in a particular area might include: (i) the number of individuals at the location, (ii) the skills and training of those individuals (iii) their engagement in violence, (iv) their engagement in ancillary operations such as planning, training, communication or propaganda and recruitment, ( $\mathrm{v}$ ) the presence of weaponry, (vi) the presence of ancillary military equipment such as surveillance and communications gear and (vii) the duration of for which any of the above persist.

The factors above are not intended to be exhaustive nor, importantly, are any of them mandatory. There may be no weaponry at the site and no violence may have been launched from that location, yet the site may still represent a 'military presence' by virtue of the other factors. For example, the location might be used solely as a recruitment, training or reconnaissance hub. ${ }^{71}$ Indeed, it is the absence of the requirement that the cell must carry out 'sustained and concerned operations" ${ }^{72}$ or dispense "intensive armed violence ${ }^{73}$ that sets the proposed approach in this article apart from the approaches discussed above. Naturally, the presence of weaponry and the execution of violence would remain indicators of military presence, but they are not essential requirements. Military commanders would be tasked with the responsibility of applying this more flexible standard and assessing whether the cell belonging to an organised armed group such as ISIS possesses the necessary degree of 'military presence' in a particular location such that the ambit of IHL stretches to cover that part of the broader NIAC. To ensure rigour and consistency, these determinations should be made at a higher level by more senior officers. Indeed, such officers already assess complex issues such as distinction and proportionality, so they have the training and skill set to perform this function also. ${ }^{74}$ After the dust has settled, courts would exercise their oversight role in ensuring that the decisions of military commanders were indeed justified and imposing individual accountability and state responsibility if they were not.

There is some limited evidence of State practice to support this 'military presence' approach. According to the US:

If an operation ... were to occur in a location where al-Qa'ida or an associated force has a significant and organized presence and from which al-Qa'ida or an associated force, including its senior operational leaders, plan attacks against U.S. persons and interests, the operation would be part of the non-international armed conflict between the United States and al-Qa'ida. ${ }^{75}$

\footnotetext{
${ }^{70}$ Kress (n 41) 266.

${ }^{71}$ Melzer (n 23) 34-35.

${ }^{72}$ Additional Protocol II (n 18) art 1(1).

${ }^{73}$ Kress (n 41) 266.

${ }^{74}$ Prosecutor v Stanislav Galic, Judgment (Trial Chamber) ICTY-989-29-T (05 December 2003) para 58.

${ }^{75}$ US Department of Justice, 'Lawfulness of a Lethal Operation Directed against a U.S. Citizen Who Is a Senior
} 
Again, the US here was linking the presence of the organised group's cell in a particular area to the ability of that cell to contribute directly to violence - in this case in the form of planning strikes against US targets. For the reasons outlined above, that clause does not seem necessary. Still, the general tenor of the statement is in line with an approach based around presence rather than control.

Tested in the manner outlined above, military presence would provide a dynamic mechanism for assessing the ambit of IHL in transnational NIACs. This dynamism is important as such conflicts exist in a constant state of flux. With this method, IHL could extend out when group members venture out and it could also be drawn back as group members retreat. This could all be done without dependence on any minimum threshold of control or violence - indeed, the latter would already have been triggered for the NIAC to exist in the first place and it need not be triggered again to include a given area within the ambit of IHL. ${ }^{76}$ There would be no reliance on international borders with such an approach - the use of which can lead to the unduly expansive application of IHL throughout a whole State notwithstanding the fact that only a small area may be in need of its regulation. ${ }^{77}$ Furthermore, under this approach, the application of IHL is unlikely to be triggered by minor events such as a single terrorist passing through an international airport which might be better described as a 'transitory' rather than a 'military' presence. However, where that individual is, say, a highly trained weapons specialist who has set up base in a warehouse from which he or she surveils targets for later attacks and in which he or she stores weapons, then that would likely qualify as a 'military presence' and IHL would apply to their location.

Returning to the case of Usman Khan, the London Bridge attacker with whom we began, his activities held clear potential to trigger the application of IHL under the approach adopted in this article. First, his actions were attributable to ISIS based on membership (and/or adoption of responsibility) ${ }^{78}$ Second, his presence in the UK amounted to 'military presence' given that his activities included plans to bomb Parliament, the London Stock Exchange, the US Embassy and other sensitive sites as well as attending terrorism-related planning meetings, preparing to travel abroad, and assisting others in travelling abroad to facilitate terrorist activities. Had the ambit of IHL been construed in the manner suggested, Khan might have been intercepted. Instead, he was treated as falling under the ambit of domestic English law and so had the benefit of criminal and human rights safeguards that he was able to rely upon to secure his original release from prison which, in turn, afforded him the opportunity to murder innocent people.

In short, 'military presence' in an area offers a more appropriate mechanism for determining the reach of IHL in transnational armed conflict than control over that area or the ability to dispense violence from it. Military presence short-circuits the shortcomings of 'control' in larger scale transnational conflicts as it acknowledges that the parties are likely to be fighting over an area precisely because they do not have control. Equally, in the smaller scale operation of 'cells' operating extra-territorially, it is flexible enough to cover individuals or small groups who are carrying out, plotting or otherwise assisting in strikes. Military presence avoids the issue of requiring that the area in question can be used to dispense violence of any intensity - while still recognising violence projection as a valid indicator among many others. Further, military presence is a more objective notion than control. Whereas their 'control' over an area (and the lack of enemy control) is a condition that military commanders and politicians are likely to want to assert, military presence is less loaded. It is easier for both sides to acknowledge the presence of the enemy on a given area of territory than acknowledging their control over that area. This will make it a more neutral, less contentious, matter

\footnotetext{
Operational Leader of Al-Qa'ida or an Associated Force' (08 November 2011, US Department of Justice)

$<$ https://bit.ly/2QDy2e2>.

${ }^{76}$ Tadic (n19) para 70.

${ }^{77}$ Kress (n 41) 266.

${ }^{78}$ Melzer (n 23) 33-35.
} 
for courts to assess after the fact.

\section{Conclusion}

The reach of IHL in the context of conflicts between States and organised armed groups is a deeply controversial issue with States increasingly pushing the boundaries while humanitarian groups vie to draw them back. This article has outlined the main contenders for determining the ambit of the regime and it seems clear that approaches based on international boundaries, 'hot battlefields', global application and territorial control simply do not fit the bill. Instead, it is increasingly evident that 'military presence' is a more apposite test when assessing the geographical extent of a transnational armed conflict as it has the ability to shrink-wrap itself around the various spurs of a broader NIAC wherever they arise in the world. The approach is not too broad: it would not, for example, cover the territory of whole states in which such groups operate. Nor is the approach too narrow: it would not only apply to areas where violence is actually raging or to areas over which organised group have established firm control. In this way, a military presence based approach to the ambit of IHL would strike a balance between the twin pillars of humanity and military necessity that provide the foundations of the law. 